\title{
ART MANAGEMENT: A NEW DISCIPLINE ENTERING THE CULTURAL AND ACADEMIC LIFE IN PLOVDIV
}

\author{
Vasil Kolev, ${ }^{1}$ Asya Ivanova ${ }^{2}$
}

\begin{abstract}
This paper presents the conditions of economic and political changes within the 90s in Bulgaria and the necessity of a new way of thinking at managing cultural institutions in the conditions of the market economy. As a response to that problem it was created the first of its kind in Bulgaria master's degree program „Art management.“

For that purpose a brief overview of the formal models of funding the arts worldwide are presented along with the characteristics at regional levels which led to the creation of the new educational programme.

The main disciplines studied in the educational module aiming to develop a new set of skills among artists are listed with a brief introduction of their scope. A local survey conducted at the Academy of Music, Dance and Fine Arts - Plovdiv, analyzing the interest of the first of its kind in Bulgaria master's degree program „Art management“ is presented.

The initial result of the evolution of the educational programme based on the number of students enrolled per year are the motivation for the start of a lager research project "ÄRT" funded by the SRF, Ministry of Education and Science.
\end{abstract}

UDC Classification: 7.1/06; DOI: http://dx.doi.org/10.12955/cbup.v5.1004

Keywords: art management; arts funding, university education

\section{Arts and management}

Art is one of the greatest achievements of human civilization. Communicating with it elevates, enriches and ennobles us making us better, wiser and more sensual. The pleasure and joy that people experience when communicating with art would not have been possible without the targeted and actual implementation of management of Art or as it's called in this specific area art management. (Busheva, Stoichkova, Aratunyan-Vasilevska, \& Konstantinova, 2014, p. 7)

One result of the political and social upheaval of the last 400 years has been the establishment of institutions designed to provide continuing support and recognition for the artist and the arts. The increasing complexity of an industrially and technologically based society hastened the shift from the artist-manager as the dominant approach to organizing and presenting the arts. As many communities began to establish arts institutions late in the nineteenth century, year-round management experts began to emerge. Many arts institutions now appear to be organized along patterns similar to large business corporations.(Byrnes, 2013, p. 24)

\section{Economic realities for the arts at $20^{\text {th }}$ century}

Although management is a unique activity growing for centuries, particularly in arts management is even more specific in terms of the final product and the need for realization not only of creative excellence, moral and cultural benefits but also financial results.

Irrespective of the large economic costs of modern developments of arts and placing them at free market conditions, there was no serious research nor any publications on the economics of the arts until the mid60s. Pioneers in the area of economics of the arts are two American scientists William Baumol and William Bowen, who in 1965 published their work "On The performing arts: The anatomy of their economic problems" after conducting vast economic research in the USA, United Kingdom, Australia and New Zealand on the economic and financial difficulties the arts were facing.

Baumol and Bowen determined the main economic principles under which the arts functioned and the real necessity of outside financial aid. They laid the foundations of the so called "positive theory of financial aid of the arts" (Baumol \& Bouen, 1965).

In the modern world there are various forms of financial support for the arts. In her work "Management of the Arts" Lydia Varbanova a Bulgarian scientist examines the evolution of the forms of State funding and the involvement of market principles in the arts world and determines the existence of three formal macroeconomic models:

- Model of full State finding of the arts- this model is spread across Central and Eastern Europe between the 50's and the 90's and its main characteristics are:

1. The State is the main financial source for development of creative organizations

2. Cultural politics are orientated to direct financing of the arts

\footnotetext{
${ }^{1}$ Academy of Music, Dance and Fine Arts, vasko_kolev@abv.bg

${ }^{2}$ Academy of Music, Dance and Fine Arts, asiaiv71@gmail.com
} 
3. There is little diversity in the forms of organization of cultural institution

4. There is stability in the development of the arts

5. There is no market for the arts

6. The arts are accessible for wide audiences

- Model for development of the arts at free market conditions - this model originated in the USA and its main characteristics are:

Main institutional form of the creative industries is private organization

1. Managers in the arts are mainly mediators between the artists and the audiences, with a main concern of selling the art product

2. There is a wide and developed market for art products and artists

3. The artists are mainly temporarily hired for a specific performance

- Mixed model for developing of the arts- this model originated in the United Kingdom and today is widely spread across Europe. The proportions between state funding and financing at market principles varies between different countries. The mixed model has the following characteristics:

1. Different sources of financing are available- state, private sector, variety of forms of charity

2. There is a wide variety in terms of purpose of creation, financial sources, forms of organization and management for the creative industries

3. Part of the art organizations are funded by the state, the rest are funded by themselves mainly with selling their art products

In the contemporary world of arts the differentiation of the tree models is more theoretical then practical. The American free market model "has been fractured" in the 60's with the creation of the National Endowment for the Arts, stabilizing the legislation for encouraging the investments in the arts and the emergence of the first non-profit organizations, today it is leaning more towards the mixed model for development of the arts. (Varbanova, 1997, pp. 46-49)

\section{The necessity of change and the response of the academic society}

In Bulgaria after the political changes in the 90's and the transition to democratic government and free market economy, the model for development of the arts has changed from "state funding" to "mixed model of funding". The state funding of the cultural industries was reduced but it is still the main source of income. The art organizations were facing the necessity of raising additional funds thru ticket sales, outside sources - sponsors, patronage and charity. In that point of time the functions of the art managers were strictly administrative, but the transition from centralized state funding and management of the arts and placing them in market conditions requires from the art managers to build a vaster and more comprehensive management skill set.

In response to the need for new management skills the Academy of Music, Dance and Fine Arts - Plovdiv developed a new educational module for Master's degree "Art management". It is the first educational program of its kind in Bulgaria. The main disciplines included in the program are:

- "Art management" - studies basic management theories, characteristics of business environment in terms of specific organizations associated with different types of art, basic management functions, the stages of the management process; It aims not only to acquire knowledge but also to develop skills to carry out all management tasks in the arts.

- "Legal Framework and Cultural Policy" - it aims to give students basic knowledge in the matter and should help them to develop sound knowledge on the use of the art products as well as ways to prevent unregulated and illegal exploitation of intellectual property.

- "Cultural Industries" - studies structure, organization and management of various art organizations in the field of cultural industries.

- "Public Relations"- studies the role and importance of communications and public relations in modern society; the connections between the concepts - public relations, popularity, marketing, advertising and publicity; the functions of PR in various organizations and their place in the organization structure.

- "Marketing" - the aim is to give basic knowledge and initial skills in marketing and advertising, developing skills to conduct market research and the organization of successful advertising.

- "Project Management"- the accession of Bulgaria to the European Union in 2007 opened new opportunities for securing additional external funding for the art organizations through 
participation in projects under the programs financed by European funds, leading to the addition of a new discipline in the tuition module

The tuition program is fully customized and aimed at developing managing and marketing skills in the field of arts at the conditions of the market economy.

As we all know any change in the routine of our lives is perceived to be difficult. The presentation of the new training module of the Academy of Music and Dance Arts raised mixed opinions and the interest in the program was not high as it can be seen from "Figure 1" representing the number of students enrolled in the specialty since its existence (please mind that the Academy is a boutique University with 800 students in total).

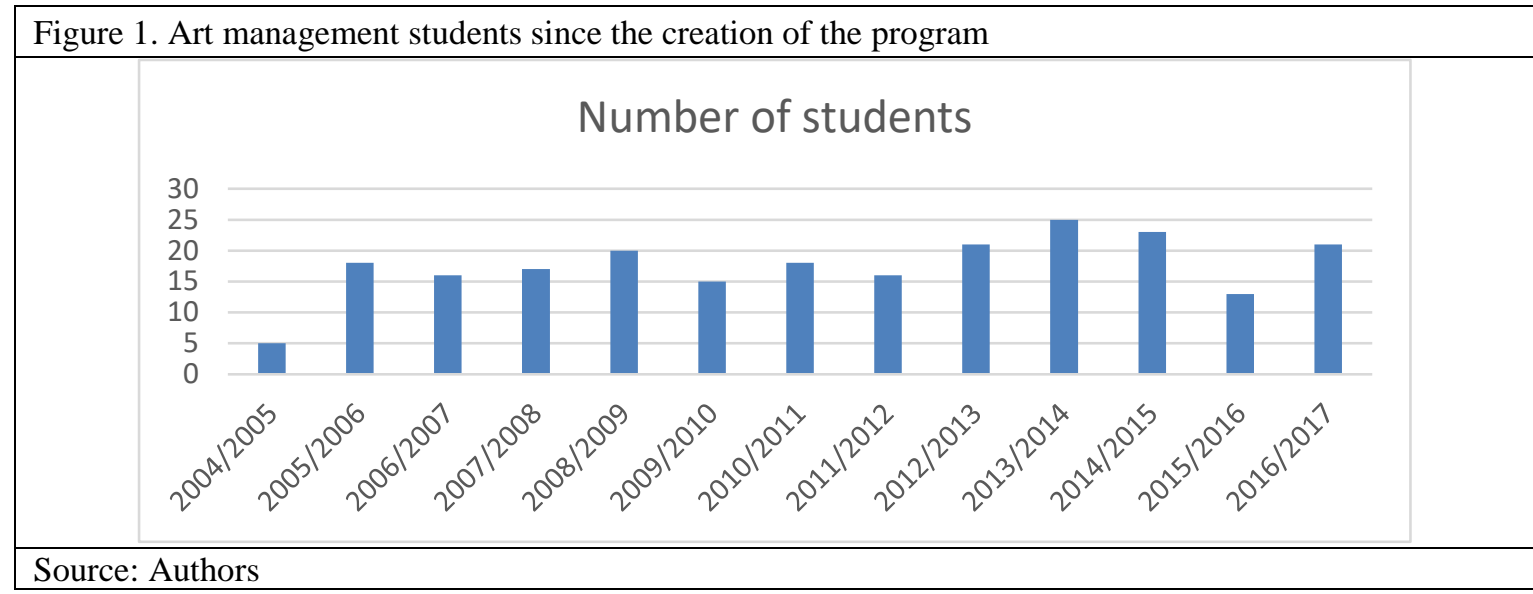

The first students who signed up for the new educational program in master's degree were bachelors from the Academy of Music, Dance and Fine Arts - Plovdiv. After graduation, the first students found easy realization as managers in the cultural industries and one of them created his own boutique theatre. In subsequent years, the interest in the specialty has increased not only from students of the Academy who perceived "Art management" as a natural development of their education, but also by managers of cultural institutions conscientious of the necessity of obtaining managerial skills. A curious fact is that after the first four years of existence of the program, interest in the specialty was expressed by people who had no previous education in the arts. The increased interest in the program and stable number of students over the years led to a natural inclusion of "Arts management" as an education module in other universities in the country under different names.

\section{Conclusion}

In conclusion, we can say that the Academy Of Music, Dance and Fine Arts laid the foundations of the "Art Management" in Plovdiv and that the impact of its development will have a beneficial effect across all cultural industries in Bulgaria. None-the-less the specialty "Art Management" is in total compliance with the idea of an university education - to create interdisciplinary and thinking professionals. The results of the survey in the Academy of Music, Dance and Fine Arts were the motivation for the initiation of a lager research project „Art management: Plovdiv - new tendencies and classical art (ART)“.

\section{Acknowledgment}

The article is founded by the project DM05/2/2016 „Art management: Plovdiv - new tendencies and classical art (ART)“, Bulgarian Science Fund, Ministry of Education and Science.

\section{References}

Baumol, W., \& Bouen, W. (1965). On the performing arts: The anatomy of their economic problems (Vol. N5). The American Economic Review.

Busheva, Z., Stoichkova, T., Aratunyan-Vasilevska, S., \& Konstantinova, E. (2014). Art Management. Plovdiv: UP "Paisii Hilendarski".

Byrnes, W. J. (2013). Management and the Arts (Vol. 4th edition). Burlington: Focal Press.

Varbanova, L. (1997). Management of the arts. Sofia: UP "Stopanstvo". 